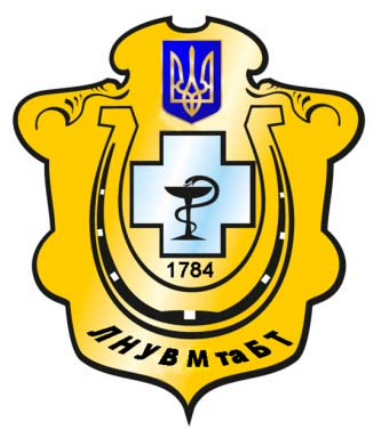

Науковий вісник Львівського національного університету ветеринарної медицини та біотехнологій імені С.3. Гжицького

Scientific Messenger of Lviv National University of Veterinary Medicine and Biotechnologies named after S.Z. Gzhytskyj

doi:10.15421/nvlvet6613

ISSN 2413-5550 print

ISSN $2518-1327$ online

$\underline{\text { http://nvlvet.com.ua/ }}$

\title{
Кістозна гіперплазія ендометрію як причина неплідності у самок собак, діагностика та лікування
}

\author{
Н.Г. Давиденко \\ natalyadavidenko@ukr.net
}

Сумський наиіональний аграрний університет,

вул. Г. Кондратьєва, 160, м.Суми, 40021, Украӥна

\begin{abstract}
В статті описується патогенез неплідності при кістозній гіперплазї ендометрію, особливості діагностики ицієї патології та консервативний метод лікування. Наведені дані про зміни гормонального фону крові, морфологічних та біохімічних показників крові у неплідних самок собак з кістозною гіперплазією ендометрію до та після лікування.

В дослідженні приймали участь 11 неплідних самок собак з кістозною гіперплазією ендеметрію, та 5 самок собак з нормальною функиією репродуктивної системи віком від 2 до 6 років. Кров відбирали у тварин в період анеструсу та метеструсу. Для лікування застосовували антибіотики широкого спектру дії, міфепристон, клопростенол та каберголін. Для контролю ефективності проведеної терапії проведено парування самок після лікування. Встановлено, що у хворих тварин були характерні зміни в морфології та біохімї крові, які відмічалися також у певної кількості самок собак після консервативного лікування. В морфологічних показниках крові у тварин до лікування та у групи тварин, щңо залишилися неплідними після лікування консервативним методом, ми спостерігали в період метеструсу такі зміни: підвищення кількості лейкоцитів, збільшення кількості паличкоядерних нейтрофілів, підвищення індексу зміщення нейтрофілів. При дослідженні біохімічних показників крові у тварин, що залишилися неплідними після лікування, були підвищені в період метеструсу активність лужної фосфатази, АЛТ, білку, креатиніну, сечовини в порівнянні з контрольною групою тварин. При дослідженні гормонального профілю крові встановлено наступні факти. Різких відмінностей рівню тироксину загального у хворих тварин та у самок собак після лікування 6 порівнянні з контрольною групою не встановлено. У хворих тварин та у групи тварин від яких не вдалося отримати приплід після лікування рівень прогестерону знижений в метеструсі, тоді як естрадіол підвищений у порівнянні з контрольною групою самок. У роботі наднирників дослідних тварин теж спостерігаються зміни. Так, функиія наднирників значно збільшується в період метеструсу, так як рівень ДГЕА-С та кортизолу підвищуються. Однак, у хворих тварин до лікування та у групи тварин, яким не вдалося завагітніти після лікування, рівень кортизолу та ДГЕА-С найнижчі, що дає підставу припустити про участь гормонів наднирників у патогенезі неплідності самок собак при кістозній гіперплазї ендометрію.

Ключові слова: кістозна гіперплазія ендометрію, неплідність, еструс, метеструс, прогестерон, естрадіол, тироксин, ДГЕА-С, пролактин, кортизол біохімічні показники сироватки крові, морфологічні показники крові.
\end{abstract}

\section{Кистозная гиперплазия эндометрия как причина бесплодия у самок собак, диагностика и лечение}

\author{
Н.Г. Давиденко \\ natalyadavidenko@ukr.net
}

Сумской наииональный аграрный университет,

ул. Г. Кондратьева, 160, г. Сумы, 40021, Украина

В статье описывается патогенез бесплодия при кистозной гиперплазии эндометрия, особенности диагностики этой патологии и консервативный метод лечения. Приведены данные об изменениях гормонального фона крови, морфологических и биохимических показателей крови у бесплодных самок собак с кистозной гиперплазией эндометрия до и после лечения.

\section{Citation:}

Davydenko, N.G. (2016). Cystic endometrial hyperplasia as a cause of infertility in female dogs, diagnosis and treatment. Scientific Messenger LNUVMBT named after S.Z. Gzhytskyj, 18, 2(66), 59-64. 
В исследовании принимали участие 11 бесплодных самок собак с кистозной гиперплазией эндометрия и 5 самок собак с нормальной функцией репродуктивной системы в возрасте от 2 до 6 лет. Кровь отбирали у животньх в период анэструса и метэструса. Для лечения применяли антибиотики широкого спектра действия, мифепристон, клопростенол и каберголин. Для контроля эффективности проведённой терапии проводили оплодотворение самок после лечения.

Установлено, что у больных животных есть характерные изменения в морфологии и биохимии крови, которые остаются также у части собак после консервативного лечения. В морфологических показателях крови у животных до лечения и у группы животных, которые остались не беременныли при повторной вязке после консервативного лечения, мы наблюдали следуюшие изменения морфологии крови в период метэструса: увеличение количества лейкочитов, увеличение количества палочкоядерных нейтрофилов, увеличение индекса сдвига нейтрофилов. При исследовании биохимических показателей крови у животных, которые не забеременели после лечения, в период метэструса были повышены активность щелочной фосфатазы, АЛТ, белка, креатинина, мочевины в сравнении с конрольной группой самок. При исследовании гормонального профиля крови выявлены следующие факты. Больших отличий уровня тироксина у больных животных и у собак после лечения в сравнении с контрольной группой не выявлено. У больных животных и у группь животных, от которых не получилось получить приплод после лечения уровень прогестерону пониженный в метеэструсе, тогда как эстрадиол повыпенный в сравнении с контрольной группой самок.

В работе надпочечников исследованных животных также наблюдаются изменения. Так, уровень ДГЭА-С и кортизола увеличиваются в период метэструса. Но, у больных животных до лечения и у группы животных, которым не удалось забеременеть после лечения, уровень кортизола и ДГЭА-С остается низким, что дает основания предположить, про участие гормонов надпочечников в патогенезе бесплодия самок собак с кистозной гиперплазией эндометрия.

Ключевые слова: кистозная гиперплазия эндометрия, бесплодие, прогестерон, эстрадиол, тироксин, ДГЭА-С, пролактин, кортизол, биохимические показатели сыворотки крови, морфологические показатели крови.

\title{
Cystic endometrial hyperplasia as a cause of infertility in female dogs, diagnosis and treatment
}

\author{
N.G. Davydenko \\ natalyadavidenko@ukr.net
}

\author{
Sumy National Agrarian University, \\ G. Kondratiev Str., 160, Sumy, 40021, Ukraine
}

The article describes the pathogenesis of infertility with cystic endometrial hyperplasia, features of diagnosis and treatment. The data on changes in hormonal, morphological and biochemical blood parameters in infertile female dogs with cystic endometrial hyperplasia before and after treatment.

The study involved 11 infertile females dogs with cystic endometrial hyperplasia and 5 female dogs with the normal function of the reproductive system from 2 to 6 years. Blood was collected during anoestrus and metestrus. For the treatment used broadspectrum antibiotics, mifepristone, cloprostenol and cabergoline. Females were fertilized again after treatment to test effectiveness of the treatment. Found that sick animals have characteristic changes in morphology and biochemistry of blood. Certain amount of the female dogs have the same changes in the blood after treatment. We observed the following changes in the morphology of the blood during metestrus in the animals before treatment and a group of animals that were not pregnant after treatment and repeated mating: increase in the number of white blood cells, increasing the number of band neutrophils, the increase in the index of neutrophil shift. In the study of biochemical blood indices we have seen elevated activity of alkaline phosphatase, ALT, protein, creatinine, urea in animals that did not become pregnant after a treatment compared with the control animals group.

During the study of hormone profile blood significant differences data of thyroxine in female dogs before and after treatment compared with the control group are not established. Patients in groups of animals and the animals from which failed to get offspring after treatment lowered levels of progesterone in metestrus while estradiol increased compared with the control group females. The paper adrenal experimental animals also observed changes. Thus, the function of the adrenal glands increases significantly during metestrus, as the level of DHEA-S and cortisol increased. However, cortisol and DHEA-S was lowest in sick animals for treatment and a group of animals that fail to conceive after treatment. It gives grounds to assume that adrenal's hormones take part in the pathogenesis of female infertility dogs with cystic endometrial hyperplasia.

Key words: cystic endometrial hyperplasia, infertility, progesterone, estradiol, thyroxine, DHEA-S, cortisol, prolactin, morphology and biochemistry of blood.

\section{Вступ}

Патологія матки - поширена причина неплідності самок собак (Dubrovina, 1999). Вона може зустрічатись у тварин різного віку (Eremina, 2002). Еструс у самок собак проходить зі спонтанною овуляцією, виникненням жовтого тіла та секрецією прогестерону приблизно 2 місяці (Israel et al., 1992; Ahanin, 1999; Dulhel, 2002). Прогестерон сприяє розростанню ендометрію в діеструс, та стимулює секрецію залоз ендометрію 3 формуванням дрібних кіст в ендометрії. В нормі ці структури піддаються регресії до початку наступного еструсу (Hoist, 1985). Якщо їх регресія не виникає, то імплантація ембріонів не можлива (Rustriz, 2010).

Таким чином хвороби матки не впливають на процес спарювання, овуляцію чи запліднення. Однак, вони впливають на можливість імплантації ембріона та розвиток нормальної вагітності (Bayard et al., 1995).

В етіології кістозної гіперплазії також має значення функція яєчників (Hoffmann et al., 1996). При кістозній гіперплазії матки у переважної більшості тварин спостерігається ендокринна дисфункція, кісти чи 
пухлини яєчників (Jones and Joshua, 1984; Simpson, 2005).

Мета та завдання дослідження. Нашою метою було дослідити патогенез та ефективність консервативного методу лікування неплідності при кістозній гіперплазії ендометрію (КГЕ). Для досягнення нашої мети були встановлені наступні завдання: дослідити морфологічні та біохімічні показники крові у неплідних самок собак з кістозною гіперплазією ендометрію до та після лікування; порівняти їх з показниками крові у здорових самок собак; дослідити гормональной фон у дослідних груп тварин у різні періоди циклу і порівняти їх 3 показниками у самок собак 3 нормальною репродуктивною функцією в аналогічний період статевого циклу; дослідити морфологію матки та яєчників у хворих тварин за допомогою УЗД; провести консервативне лікування неплідних самок собак за сучасними ефективними методиками та оцінити їх ефективність при повторному паруванні самок собак.

\section{Матеріал і методи досліджень}

В дослідженні приймали участь 11 неплідних самок собак з КГЕ, та 5 самок собак $з$ нормальною функцією репродуктивної системи віком від 2 до 6 років. У тварин проводили дослідження вмісту гормонів в сироватці периферичної крові, а також біохімічні та морфологічні показники крові. Для досліджень кров відбирали в один час, в період анеструсу та в період діеструсу, з підшкірної вени передпліччя з дотриманням правил асептики та антисептики. Для дослідження морфологічних показників крові додавали антикоагулянт гепарин: 1 крапля на 1 мл крові. Для визначення вмісту гормонів та біохімічних показників крові використовували сироватку крові.

При дослідженні морфологічних показників визначалась кількість еритроцитів та лейкоцитів шляхом прямого їх підрахунку в камері Горяєва. Лейкоцитарна формула підраховувалась методом їх прямого диференційованого підрахунку 200 лейкоцитів в мазках, пофарбованих за Романовським-Гімзою. Концентрацію гемоглобіну визначали ціанметгемоглобіновим методом.

Біохімічне дослідження сироватки проводили за загальноприйнятими методиками за допомогою біохімічного аналізатора Bio Chem. При цьому визначали наступні показники: концентрацію глюкози, загального білка, сечовини, креатинину, холестерину, кальцію, фосфору, активність аланінамінотрансамінази, аспартатамінотрансамінази, лужної фосфатази.

Для встановлення можливих порушень гормональної регуляції статевого циклу у самок собак проводили визначення концентрації прогестерону, естрадіолу, загального тироксину, пролактину, дегідроепінандростерон-сульфату (ДГЕА-С), кортизолу. Визначення концентрації кортизолу, ДГЕА-С та пролактину проводили методом твердофазного імуноферментного аналізу за допомогою набору реагентів Нема. Прогестерон, естрадіол та тироксин загальний визна- чали за допомогою електрохемілюмінісцентного аналізу набором реагентів Roche на аналізаторі Cabas.

Було сформовано 4 групи тварин: 1-ша група неплідні самки собак з кістозною гіперплазією ендометрію до лікування; 2-га група - самки собак після лікування, яких вдалося запліднити після лікування; 3-я - самки собак, від яких після лікування не було отримано приплід; 4-та - клінічно здорові самки собак, які були запліднені без лікування.

Кров відбирали у тварин в період метеструсу на 4-5 тиждень від початку метеструсу. Діагностику патології у неплідних самок проводили за результатами клінічного огляду, ультразвуковим методом дослідження репродуктивної системи.

Для лікування застосовували антибіотики широкого спектру дії; міфепристон - 10 мг/кг 1 раз на тиждень 6 тижнів; клопростенол - 1,5 мкг/кг на добу, щоденно 2 р.день 5днів; каберголін - 5 мкг/кг щоденно 1 р. день 5 днів.

\section{Результати та їх обговорення}

Результати дослідження морфологічних показників крові неплідних самок собак з кістозною гіперплазією ендометрію та клінічно здорових самок собак представлені у таблиці 1.

За результатами дослідження морфологічного складу крові ми бачимо, що гемоглобін у тварин 1-ої та 3-ої груп має найнижчі показники, однак суттєво не відрізняється від рівня у здорових тварин.

В кількості еритроцитів ми також не спостерігаємо змін, що виходять за межі фізіологічної норми.

Однак кількість лейкоцитів у тварин 1-ої та 3-ої групи суттєво підвищена, що вказує на наявність запального процесу в організмі дослідних самок. На присутність запалення також вказують зміни у лейкоцитарній формулі, а саме: підвищена кількість нейтрофілів паличкоядерних та, відповідно, високий індекс зміщення. Слід звернути увагу, що у 3-ої групи тварин, які пройшли курс лікування ознаки запалення спостерігалися лише в період метеструсу, тоді як в анеструсі вони були відсутні. I слід відмітити, що кількість паличкоялерних нейтрофілів та індекс зміщення у тварин третьої групи були вищими, ніж у тварин до лікування.

Результати дослідження біохімічних показників крові неплідних самок собак з кістозною гіперплазією ендометрію представлені у таблиці 2.

При дослідженні біохімічних показників крові виявлено підвищення концентрації лужної фосфатази у тварин першої та третьої групи в період метеструсу. Також незначно підвищена активність АЛТ у тварин третьої групи в період метеструсу. Всі інші показники знаходяться в межах фізіологічної норми. Порівнюючи дані, ми бачимо, що ряд показників: загальний білок, сечовина, креатинін, АСТ, АЛТ є найвищими у тварин третьої групи в період метеструсу. Припускаємо, що це реакція організму на запалення та інтоксикацію. 
Таблиия 1

Морфологічні показники крові самок собак $(\mathrm{M} \pm \mathbf{m})$

\begin{tabular}{|c|c|c|c|c|c|c|c|}
\hline \multirow[t]{2}{*}{ Показники } & \multirow{2}{*}{$\begin{array}{c}\text { 1-ша гру- } \\
\text { па, гол., } \\
\text { n=11 } \\
\text { діеструс } \\
\end{array}$} & \multicolumn{2}{|c|}{ 2-га група, гол., n=7 } & \multicolumn{2}{|c|}{ 3-тя група, гол., n=4 } & \multicolumn{2}{|c|}{ 4-та група, гол., n=5 } \\
\hline & & анеструс & діеструс & анеструс & діеструс & анеструс & діеструс \\
\hline Гемоглобін, г/л & $\begin{array}{c}94 \pm 13,32 \\
* * *\end{array}$ & $\begin{array}{c}98 \pm 5,53 \\
* * *\end{array}$ & $\begin{array}{l}97,14 \pm 9,5 \\
* * *\end{array}$ & $\begin{array}{c}76,8 \pm 20,44 \\
* * *\end{array}$ & $\begin{array}{l}98,8 \pm 0,4 \\
\quad * * *\end{array}$ & $\begin{array}{l}97,6 \pm 8,0 \\
* * *\end{array}$ & $\begin{array}{c}104 \pm 11,22 \\
* * *\end{array}$ \\
\hline Еритроцити, млн/мл & $\begin{array}{c}5,74 \pm 0,75 \\
* * *\end{array}$ & $\begin{array}{c}4,07 \pm 0,39 \\
* * *\end{array}$ & $\begin{array}{c}6,057 \pm 1,3 \\
* * *\end{array}$ & $\begin{array}{c}4,8 \pm 0,5 \\
* * *\end{array}$ & $\begin{array}{c}4,7 \pm 0,46 \\
* * *\end{array}$ & $\begin{array}{c}3,97 \pm 0,54 \\
* * *\end{array}$ & $\begin{array}{c}6,56 \pm 1,79 \\
* * *\end{array}$ \\
\hline Лейкоцити, тис/мл & $\begin{array}{c}17,9 \pm 2,9 \\
* * *\end{array}$ & $\begin{array}{c}8,6 \pm 1,4 \\
* * *\end{array}$ & $\begin{array}{c}11,7 \pm 3,6 \\
* * *\end{array}$ & $\begin{array}{c}8,35 \pm 1,85 \\
* * *\end{array}$ & $\begin{array}{c}17,65 \pm 4,36 \\
* * *\end{array}$ & $\begin{array}{c}9,96 \pm 1,58 \\
* * *\end{array}$ & $\begin{array}{c}5,3 \pm 0,9 \\
* * *\end{array}$ \\
\hline $\begin{array}{l}\text { Нейтрофіли палич- } \\
\text { ки, \% }\end{array}$ & $\begin{array}{l}14,27 \pm 2,9 \\
* * *\end{array}$ & $\begin{array}{c}5,6 \pm 1,0 \\
* * *\end{array}$ & $\begin{array}{c}10,9 \pm 3,86 \\
* * *\end{array}$ & $\begin{array}{c}6,5 \pm 1,38 \\
* * *\end{array}$ & $\begin{array}{c}17,5 \pm 4,05 \\
* * * \\
\end{array}$ & $\begin{array}{c}5,22 \pm 1,58 \\
* * *\end{array}$ & $\begin{array}{c}3,84 \pm 1,66 \\
* * *\end{array}$ \\
\hline $\begin{array}{l}\text { Нейтрофіли сегмен- } \\
\text { тоядерні, \% }\end{array}$ & $\begin{array}{l}64,7 \pm 5,2 \\
* * *\end{array}$ & $\begin{array}{c}71,72 \pm 5,14 \\
* * *\end{array}$ & $\begin{array}{c}67,71 \pm 6,96 \\
* * *\end{array}$ & $\begin{array}{c}72,25 \pm 5,07 \\
* * *\end{array}$ & $\begin{array}{l}57,25 \pm 7,5 \\
* * *\end{array}$ & $\begin{array}{c}68 \pm 6,58 \\
* * *\end{array}$ & $\begin{array}{c}76,6 \pm 5,3 \\
* * *\end{array}$ \\
\hline Моноцити, \% & $\begin{array}{l}4,8 \pm 1,2 \\
* * *\end{array}$ & $\begin{array}{c}1,85 \pm 0,48 \\
* * *\end{array}$ & $\begin{array}{c}4,33 \pm 1,36 \\
* * *\end{array}$ & $\begin{array}{l}0,55 \pm 0,93 \\
* * *\end{array}$ & $\begin{array}{l}5,25 \pm 1,9 \\
* * *\end{array}$ & $\begin{array}{l}2,62 \pm 0,73 \\
* * *\end{array}$ & $\begin{array}{c}1,24 \pm 0,56 \\
* * *\end{array}$ \\
\hline Лімфоцити, \% & $\begin{array}{c}15,18 \pm 2,6 \\
* * *\end{array}$ & $\begin{array}{c}21 \pm 5,13 \\
* * *\end{array}$ & $\begin{array}{c}16,42 \pm 4,21 \\
* * *\end{array}$ & $\begin{array}{c}19,25 \pm 3,092 \\
* * *\end{array}$ & $\begin{array}{c}18 \pm 4,1 \\
* * *\end{array}$ & $\begin{array}{c}23,4 \pm 7,16 \\
* * *\end{array}$ & $\begin{array}{c}12,8 \pm 4,29 \\
* * *\end{array}$ \\
\hline Еозинофіли, \% & $\begin{array}{c}1,18 \pm 0,16 \\
* * *\end{array}$ & $\begin{array}{c}0,85 \pm 0.28 \\
\quad * * *\end{array}$ & $\begin{array}{c}0,71 \pm 0,4 \\
* * *\end{array}$ & $\begin{array}{c}0,83 \pm 0,73 \\
* * *\end{array}$ & $\begin{array}{c}0 \\
* * *\end{array}$ & $\begin{array}{c}1,26 \pm 0,7 \\
* * *\end{array}$ & $\begin{array}{c}1,06 \pm 0,61 \\
* * *\end{array}$ \\
\hline Індекс зміщення & $\begin{array}{c}0,221 \pm 0,068 \\
* * *\end{array}$ & $\begin{array}{c}0.077 \pm 0,019 \\
* * *\end{array}$ & $\begin{array}{c}0,21 \pm 0,099 \\
* * *\end{array}$ & $\begin{array}{l}0,36 \pm 0,14 \\
* * *\end{array}$ & $\begin{array}{c}0,095 \pm 0,024 \\
* * *\end{array}$ & $\begin{array}{c}0,076 \pm 0,026 \\
* * *\end{array}$ & $\begin{array}{c}0,05 \pm 0,021 \\
* * *\end{array}$ \\
\hline
\end{tabular}

Примітка. * $-\mathrm{p}<0,05,{ }^{* *}-\mathrm{p}<0,01,{ }^{* * *}-\mathrm{p}<0,001$ в порівнянні 3 клінічно здоровими.

Таблиця 2

Біохімічні показники крові самок собак (M \pm m)

\begin{tabular}{|c|c|c|c|c|c|c|c|}
\hline \multirow{2}{*}{ Показники } & \multirow{2}{*}{$\begin{array}{c}\text { 1-ша група, } \\
\text { гол., } \mathrm{n}=11 \\
\text { діеструс }\end{array}$} & \multicolumn{2}{|c|}{ 2-га група, гол., n = 7} & \multicolumn{2}{|c|}{ 3-тя група, гол., n = 4} & \multicolumn{2}{|c|}{ 4-та група, гол., n = 5 } \\
\hline & & анеструс & діеструс & анеструс & діеструс & анеструс & діеструс \\
\hline $\begin{array}{l}\text { Загальний } \\
\text { білок, г/л }\end{array}$ & $\begin{array}{c}66,8 \pm 3,4 \\
* * *\end{array}$ & $\begin{array}{c}52,1 \pm 3,02 \\
* * *\end{array}$ & $\begin{array}{c}59,3 \pm 5,72 \\
* * *\end{array}$ & $\begin{array}{c}55,45 \pm 7,8 \\
* * *\end{array}$ & $\begin{array}{c}69,72 \pm 5,11 \\
* * *\end{array}$ & $\begin{array}{c}49,7 \pm 5,6 \\
* * *\end{array}$ & $\begin{array}{c}46,5 \pm 7,1 \\
* * *\end{array}$ \\
\hline $\begin{array}{l}\text { Глюкоза } \\
\text { ммоль/л }\end{array}$ & $\begin{array}{c}3,87 \pm 0,5 \\
* * *\end{array}$ & $\begin{array}{l}5,1 \pm 0,5 \\
* * *\end{array}$ & $\begin{array}{c}4,257 \pm 0,66 \\
* * *\end{array}$ & $\begin{array}{c}4,47 \pm 0,52 \\
* * *\end{array}$ & $\begin{array}{c}4,35 \pm 0,93 \\
* * *\end{array}$ & $\begin{array}{c}5,54 \pm 0,61 \\
* * *\end{array}$ & $\begin{array}{c}4,87 \pm 0,31 \\
* * *\end{array}$ \\
\hline Холестерин & $\begin{array}{c}4,2 \pm 0,28 \\
* * *\end{array}$ & $\begin{array}{c}2,95 \pm 0,2 \\
* * *\end{array}$ & $\begin{array}{c}3,73 \pm 0,49 \\
* * *\end{array}$ & $\begin{array}{l}9,2 \pm 6,7 \\
* * *\end{array}$ & $\begin{array}{c}4,13 \pm 0,8 \\
* * *\end{array}$ & $\begin{array}{c}2,98 \pm 014 \\
* * *\end{array}$ & $\begin{array}{c}3,05 \pm 0,37 \\
* * *\end{array}$ \\
\hline $\begin{array}{l}\text { Сечовина, } \\
\text { ммоль/л }\end{array}$ & $\begin{array}{c}6,2 \pm 1,34 \\
* * *\end{array}$ & $\begin{array}{c}7,14 \pm 2,38 \\
* * *\end{array}$ & $\begin{array}{c}7,67 \pm 1,95 \\
* * *\end{array}$ & $\begin{array}{l}5,1 \pm 1,2 \\
* * *\end{array}$ & $\begin{array}{c}8,18 \pm 2,77 \\
* * *\end{array}$ & $\begin{array}{c}5,17 \pm 0,44 \\
* * *\end{array}$ & $\begin{array}{c}4,24 \pm 0,78 \\
* * *\end{array}$ \\
\hline $\begin{array}{l}\text { Креатинін, } \\
\text { мкмоль/л }\end{array}$ & $\begin{array}{c}90,2 \pm 8,5 \\
* * *\end{array}$ & $\begin{array}{c}95,77 \pm 11,12 \\
* * *\end{array}$ & $\begin{array}{c}94,3 \pm 10,8 \\
* * *\end{array}$ & $\begin{array}{c}94,2 \pm 19,5 \\
* * *\end{array}$ & $\begin{array}{c}103,95 \pm 13,95 \\
* * *\end{array}$ & $\begin{array}{c}75,76 \pm 4,42 \\
* * *\end{array}$ & $\begin{array}{c}88,72 \pm 7,03 \\
* * *\end{array}$ \\
\hline АЛТ, Од/л & $\begin{array}{c}42,8 \pm 4,9 \\
* * *\end{array}$ & $\begin{array}{c}29,63 \pm 6,83 \\
* * *\end{array}$ & $\begin{array}{c}34,5 \pm 8,1 \\
* * *\end{array}$ & $\begin{array}{c}32,15 \pm 11,32 \\
* * *\end{array}$ & $\begin{array}{c}55,53 \pm 16,11 \\
* * *\end{array}$ & $\begin{array}{c}25,24 \pm 5,43 \\
* * *\end{array}$ & $\begin{array}{c}27,2 \pm 7,67 \\
* * *\end{array}$ \\
\hline АCТ, Од/л & $\begin{array}{c}46,6 \pm 5,6 \\
* * *\end{array}$ & $\begin{array}{c}33,93 \pm 4,2 \\
* * *\end{array}$ & $\begin{array}{c}38,99 \pm 6,181 \\
* * *\end{array}$ & $\begin{array}{c}36,73 \pm 6,79 \\
* * *\end{array}$ & $\begin{array}{c}48 \pm 12,73 \\
* * *\end{array}$ & $\begin{array}{c}32,76 \pm 4,9 \\
* * *\end{array}$ & $\begin{array}{c}26,9 \pm 2,3 \\
* * *\end{array}$ \\
\hline $\begin{array}{l}\text { Лужна фос- } \\
\text { фатаза, Од/л }\end{array}$ & $\begin{array}{c}202,67 \pm 25,8 \\
* * *\end{array}$ & $\begin{array}{c}34,67 \pm 1,84 \\
* * *\end{array}$ & $\begin{array}{c}105,8 \pm 15,3 \\
* * *\end{array}$ & $\begin{array}{c}33,25 \pm 0,89 \\
* * *\end{array}$ & $\begin{array}{c}174,93 \pm 68,64 \\
* * *\end{array}$ & $\begin{array}{c}21,92 \pm 3,63 \\
* * *\end{array}$ & $\begin{array}{c}73,38 \pm 13,13 \\
* * *\end{array}$ \\
\hline
\end{tabular}

Результати дослідження концентрації гормонів в сироватці крові неплідних самок собак 3 кістозною гіперплазією ендометрію та клінічно здорових самок собак представлені у таблиці 3.

За результатами досліджень рівню пролактину у дослідних самок собак в період анеструсу його рівень у всіх групах був низький і склав $0,17-0,26$ нг/мл. Його рівень в період метеструсу збільшився у всіх групах, однак у тварин першої дослідної групи він був найвищим і склав $3,02 \pm 0,5$ нг/мл $(\mathrm{p}<0,001)$, що в 2,75 рази більше в порівнянні з його рівнем у тварин контрольної групи.

Рівень прогестерону в період анеструсу у тварин другої та контрольної груп був низьким і склав $0,3 \pm$ 0,05 нг/мл $(\mathrm{p}<0,001)$ та 0,2840,3 $\pm 0,072$ нг/мл $(\mathrm{p}<$ $0,001)$ відповідно. У тварин третьої групи в анеструсі він теж залишався низьким, однак, в порівнянні 3 контрольною групою він був вищим у 8,1 рази, що вказує на його синтез в організмі хворих собак в період анеструсу.

В метеструсі рівень прогестерону значно підвищується у всіх групах. Найвищий він у тварин другої та четвертої груп. Найнижчий він у самок третьої групи. Його рівень $7,77 \pm 2,24$ нмоль/л $(\mathrm{p}<0,001)$, що в 5,4 рази менше в порівнянні 3 контрольною групою тварин.

Аналізуючи данні рівню естрадіолу в крові у дослідних тварин, слід відмітити, що його рівень в анеструсі у тварин другої та четвертої групи є дещо вищим ніж в метеструсі, однак інша ситуація у тварин третьої групи: рівень в анеструсі його становить $6,69 \pm$ 2,88 пг/мл $(\mathrm{p}<0,001)$, що нижче ніж у тварин контро- 
льної групи, однак в період метеструсу рівень його зростає і складає 49,25 $\pm 37,49$ пг/мл (р < 0,001), що в 2,4 рази більше, ніж у контрольної групи собак. Це вказує на продукцію естрогенів фолікулярною кістою яєчників у цих тварин, що підтвердили при ультразвуковому дослідженні яєчників.
Тироксин загальний у всіх тварин був в межах норми. У першої групи тварин до лікування він був найнижчим, що може бути наслідком хронічного запалення.

За рівнем кортизолу та ДГЕА-С ми оцінюємо роботу наднирників самок собак, які беруть участь також і в утворенні статевих гормонів (Dulhel, 2002).

Таблиця 3

Вміст гормонів в сироватці крові самок собак $(\mathbf{M} \pm \mathbf{m})$

\begin{tabular}{|c|c|c|c|c|c|c|c|}
\hline \multirow[t]{2}{*}{ Показники } & \multirow{2}{*}{$\begin{array}{c}\text { 1-ша група, } \\
\text { гол., } \mathrm{n}=11 \\
\text { діеструс }\end{array}$} & \multicolumn{2}{|c|}{ 2-га група, гол., n = 7} & \multicolumn{2}{|c|}{ 3-тя група, гол., n = 4} & \multicolumn{2}{|c|}{ 4-та група, гол., n = 5} \\
\hline & & анеструс & діеструс & анеструс & діеструс & анеструс & діеструс \\
\hline Пролактин нг/мл & $\begin{array}{c}3,02 \pm 0,5 \\
* * *\end{array}$ & $\begin{array}{c}0,17 \pm 0,015 \\
* * *\end{array}$ & $\begin{array}{c}0,912 \pm 0,45 \\
* * *\end{array}$ & $\begin{array}{c}0,18 \pm 0,03 \\
* * *\end{array}$ & $\begin{array}{c}0,58 \pm 0,08 \\
* * *\end{array}$ & $\begin{array}{c}0,26 \pm 0,87 \\
* * *\end{array}$ & $\begin{array}{c}1,1 \pm 0,628 \\
* * *\end{array}$ \\
\hline $\begin{array}{l}\text { Прогестерон, } \\
\text { нмоль/л }\end{array}$ & $\begin{array}{c}11,33 \pm 2,075 \\
* * *\end{array}$ & $\begin{array}{c}0,3 \pm 0,05 \\
* * *\end{array}$ & $\begin{array}{c}31,73 \pm 14,88 \\
* * *\end{array}$ & $\begin{array}{c}2,3 \pm 1,92 \\
* * *\end{array}$ & $\begin{array}{c}7,77 \pm 2,24 \\
* * *\end{array}$ & $\begin{array}{c}0,284 \pm 0,072 \\
* * *\end{array}$ & $\begin{array}{c}41,72 \pm 19,41 \\
* * *\end{array}$ \\
\hline Естрадіол, пг/мл & $81 \pm 8,0 * * *$ & $\begin{array}{c}9,53 \pm 4,0 \\
* * *\end{array}$ & $\begin{array}{c}8,53 \pm 2,16 \\
* * *\end{array}$ & $\begin{array}{c}6,69 \pm 2,88 \\
* * *\end{array}$ & $\begin{array}{c}49,3 \pm 37,5 \\
* * *\end{array}$ & $\begin{array}{c}16,097 \pm 5,85 \\
* * *\end{array}$ & $\begin{array}{c}11,82 \pm 1,77 \\
* * *\end{array}$ \\
\hline $\begin{array}{l}\text { Тироксин зага- } \\
\text { льний, нмоль/л }\end{array}$ & $\begin{array}{c}16,35 \pm 3,66 \\
* * *\end{array}$ & $\begin{array}{c}30,49 \pm 6,36 \\
* * *\end{array}$ & $\begin{array}{c}30,25 \pm 2,4 \\
* * *\end{array}$ & $\begin{array}{c}37,99 \pm 9,9 \\
* * *\end{array}$ & $\begin{array}{c}32,42 \pm 4,68 \\
* * *\end{array}$ & $\begin{array}{c}41,73 \pm 6,5 \\
* * *\end{array}$ & $\begin{array}{c}33,36 \pm 1,79 \\
* * *\end{array}$ \\
\hline ДГЕА-С, мкг/мЛ & $\begin{array}{c}0,055 \pm 0,04 \\
* * *\end{array}$ & $0,1 * * *$ & $\begin{array}{c}0,56 \pm 0,3 \\
* * *\end{array}$ & $0,1 * * *$ & $\begin{array}{l}0,6 \pm 0,5 \\
* * *\end{array}$ & $0,1 * * *$ & $\begin{array}{c}0,74 \pm 0,39 \\
* * *\end{array}$ \\
\hline $\begin{array}{l}\text { Кортизол } \\
\text { нмоль/л }\end{array}$ & $\begin{array}{c}128,75 \pm 60,25 \\
* * *\end{array}$ & $\begin{array}{c}70,5 \pm 26,32 \\
* * *\end{array}$ & $\begin{array}{c}176,19 \pm 38,26 \\
* * *\end{array}$ & $\begin{array}{c}33,83 \pm 7,4 \\
* * *\end{array}$ & $\begin{array}{c}84,2 \pm 28,4 \\
* * *\end{array}$ & $\begin{array}{c}151,94 \pm 43,69 \\
* * *\end{array}$ & $\begin{array}{c}193,96 \pm 48,96 \\
* * *\end{array}$ \\
\hline
\end{tabular}

ДГЕА-С у всіх тварин залишався низьким в анестpусі і збільшився в метеструсі. Найвищі показники ДГЕА-С були в контрольної групи тварин.

Кортизол також був в межах норми і в анеструсі мав нижчі показники, ніж в метеструсі. Однак слід відзначити, що у тварин першої та третьої групи рівень кортизолу був знижений. Найвищий рівень кортизолу мали тварини контрольної групи.

Перспективою в подальших дослідженнях є дослідження гормонального фону крові після хірургічного лікування яєчників у таких неплідних тварин. Паралельне дослідження гістологічних змін в матці та яєчниках у хворих тварин та після лікування буде корисним для розуміння патогенезу захворювання та підтвердження ефективності лікування. Також дослідження інших причин неплідності та їх патогенезу є необхідним для розуміння механізму гормональною регуляції, що забезпечує репродуктивну функцію у самок собак.

\section{Висновки}

В морфологічних показниках крові у тварин до лікування та у групи тварин, що залишилися неплідними після лікування консервативним методом ми спостерігали в період метеструсу такі зміни: підвищення кількості лейкоцитів, збільшення кількості паличкоядерних нейтрофілів, підвищення індексу зміщення нейтрофілів.

При дослідженні біохімічних показників крові у тварин, що залишилися неплідними після лікування, були підвищені активність лужної фосфатази, АЛТ, білку, креатиніну, сечовини в порівнянні з контрольною групою тварин лише в період діеструсу.

При дослідженні гормонального профілю крові у тварин першої та третьої групи, в порівнянні з другою та четвертою групою тварин був знижений рівень прогестерону, оскільки тварини першої та третьої груп були невагітними в період досліджень крові, на відміну від самок другої та четвертої груп.

Рівень естрадіолу у тварин першої та третьої груп він різко збільшений в період метеструсу, що дає вказує на секрецію естрогенів у цих тварин.

Рівень ДГЕА-С та кортизолу збільшувався значно в період метеструсу, однак, у хворих тварин та у тварин, яким не вдалося завагітніти після лікування рівень кортизолу та ДГЕА-С найнижчі, що дає підставу припустити про їх участь у патогенезі неплідності самок собак при кістозній гіперплазії едометрію.

\section{Бібліографічні посилання}

Ahanin, A.V. (1999). Spravochnik veterenarnoho vracha [Veterinarian guide]. Rostov-na-Donu: Feniks (in Russian).

Dubrovina, Ye. (1999). Opyt lecheniia narusheniia polovoho tsykla i eho oslozhnenij u sobak [Experience in the treatment of disorders of sexual cycle and its complications in dogs]: 7ia Mezhdunarodnaja konferentsiia po problemam veterenarnoi medicine melkih domdshnih zhivotnuh $-7^{\text {th }}$ International conference on the problems of veterinary medicine of small animals. Moskow (in Russian).

Dulhel, H.P. (2002). Fisiologija razmnozheniia i reproductivnaja patologija sobak [Reproductive physiology and reproductive pathology of dogs]. Moscow: Kolos (in Russian).

Eremina L.V. (2002). Diagnostika akusherskohinekolohicheskih zabolevanij u sobak po dannum hematolohicheskih i tsitolohicheskih issledovanij [Diagnosis of obstetrics and gynecological diseases in dogs by Dunn hematological and cytological studies]: 7ia Mezhdunarodnaja konferentsiia po problemam veterenarnoi medicine melkih domdshnih zhivotnuh - 
7th International conference on the problems of veterinary medicine of small animals. Moskow (in Russian).

Simpson, J. (2005). Rukovodstvo po reprodukcii i neotolohiji sobak i koshek [Guide reproduction and neonatal dogs and cats]. Moskow: Sophion (in Russian).

Bayard, F., Monrozies, M., Boulard, F. (1995) Endometrlcal progesterone concentrations during the menstrual cycle. J.clin.endocr. 41, 135, 412-414.

Israel, R., Mishel D.R., \& Stone S.C.(1992). Single luteal phase serum progesterone assayasan indicator of ovulation. Am. J. Obstet. Gynec. 122, 1043-1046.
Hoffmann, B., Riesenbeck, A., Klein, R. (1996) Reproductive endocrinology of bitches. Anim. Reprod. Sci. 42, 275-288.

Hoist, P.A. (1985) Canine reproduction. Colorado: Alpine Publications.

Jones, D.E., Joshua, J.O. (1984) Reproductive clinical problems in the dog - London: Wright.

Rustriz, M.R. (2010) Clinical canine and feline reproduction. University of Minesota college of veterinary medicine: Wiley-Blackwell.

Стаття надійшла до редакиї̈ 15.09.2016 